\title{
Evaluation of Stability and Performance of Dam Foundations at Static State
}

\author{
Ebrahim Ghanizadeh ${ }^{1}$, Mohammad Ghanizadeh ${ }^{2}$
}

\begin{abstract}
Dams possess high economic and political importance. They play critical role in agriculture, development of urban and rural areas, supplying drink water, generation of hydroelectric energy, control and regulation of water current velocity. Protection, retention and permanent evaluation of dam's stability is major issue regarding high cost associated with dam construction and severity of consequences caused by dam instability. Since increased safety of dam is always accompanies with increased cost, it is necessary to ensure dam stability through designing, implanting and exploiting steps. Application of accurate instrument and behavior survey in engineering projects provides a permanent control over the execution trend and optimization of execution procedure in proportion to real status of stability. Thus it is vital to make suitable use of dam behavior survey and similar experiences to control dam's stability and safety through designing, execution and exploitation phases. FLAC is a powerful multi-purpose software in geotechnical projects that is widely used to analyze dam stability based on finite difference method. The present study analyzes an embankment dam. By modeling of dam finite difference in the software and implementing earthquake scale, the effect of this earthquake on the dam is studied and suitable methods for dam and foundation stability were achieved. Stability causes hydrodynamic effects on the dam body and affects magnitude and distribution of static stresses as well.
\end{abstract}

Keywords: static analysis, embankment dam, foundation, FLAC

\section{Introduction}

As an earthquake vulnerable country, Iran has experienced devastating earthquakes during recent years. Iran condition regarding earthquake occurrence makes it necessary to secure the society and buildings against earthquake. Considering the large number of dams constructed in earthquake vulnerable regions, and probable construction of additional dams in these regions, it is of great priority to make them safe against earthquake. In general, embankment dams are three dimensional, heterogeneous, non-isotopic, non-elastic and multi-phase constructs (containing grains, water and air) that interact with foundation and reservoir water. Comprehensive numerical methods that cover all of abovementioned factors are complex, costly and time consuming and depend on dominant conditions. Many issues especially those involved in three dimensional and non-elastic nature of dam's ingredients have been addressed during recent years as a result of progresses made in software and hardware fields. Moreover, development of laboratory and field techniques for evaluation of dam ingredients and historical materials together with forced vibration effects on dams have made considerable contribution to validation and authentication of analytical and numerical 
methods. Stability is evaluated by experienced engineers who are familiar with earthquake description problems, materials' properties and limitations of numerical and analytical methods and have sufficient knowledge about already constructed dams against earthquakes. According to the results published by International Commission on Large Dams (ICOLD), it is evident that until 1984, 12 embankment dams were destroyed by earthquake and 40-50 dams suffered from damages such as crest's crack, increased slope and local failures. Some of these damages are presented in table 1.

Table1. Effect of earthquake on a number of embankment dams (Pedro, 1993).

\begin{tabular}{|ll|lll|l|l|l|}
$\begin{array}{l}\text { Earthquake } \\
\text { severity }\end{array}$ & $\begin{array}{l}\text { Damage } \\
\text { Year }\end{array}$ & Country & $\begin{array}{l}\text { Construction } \\
\text { type }\end{array}$ & $\begin{array}{l}\text { Height } \\
(\mathrm{m})\end{array}$ & Dam \\
\hline 7.6 & $\begin{array}{l}\text { Longitudinal } \\
\text { cracks }\end{array}$ & 1981 & Mexico & Rockfill & 148 & $\begin{array}{l}\text { El } \\
\text { Infiernillo }\end{array}$ \\
\hline 6.3 & $\begin{array}{l}\text { Complete } \\
\text { failure }\end{array}$ & 1925 & U.S & $\begin{array}{l}\text { Homogeneous } \\
\text { dam }\end{array}$ & 7.5 & Sheffield \\
\hline 6 & $\begin{array}{l}\text { crest } \\
\text { subsidence }\end{array}$ & 1980 & U.S & $\begin{array}{l}\text { Homogeneous } \\
\text { dam }\end{array}$ & 60 & $\begin{array}{l}\text { Long } \\
\text { Valley }\end{array}$ \\
\hline 5.7 & $\begin{array}{l}\text { crest } \\
\text { subsidence }\end{array}$ & 1975 & U.S & Rockfill & 235 & Orwell \\
\hline 6.6 & Liquefaction & 1971 & U.S & Hydraulic & 42 & $\begin{array}{l}\text { Saint } \\
\text { Fernando }\end{array}$ \\
\hline
\end{tabular}

Fujinuma Dam represents a recent example which was completely destroyed during Tokyo 9-Richter earthquake in 2011. The cause of this destruction was water spillway due to waves caused by the earthquake (dam reservoir was at peak height in the event day) (Pradel \& et al 2013). Damages caused by earthquake, as depicted in Table 1, can categorized as follows (Cook et al, 1989).

- Dam failure and collapse due to presence of main fault in the base of the dam

- $\quad$ Crack of dam faces due to earthquake

- $\quad$ Loss of free height due to imbalanced subsidence in the region

- $\quad$ Loss of free height due to wall slippage and dam widening

- Dam slippage on weak layers

- Spillway due to waves formed on the water surface

- $\quad$ Spillway due to unexpected occurrence of land slippage in the reservoir

- Liquefaction of low density saturated sands or loss of unsaturated clays resistance

- Longitudinal or latitudinal cracks

- $\quad$ Piping type damages due to cracks caused by land movement

Among abovementioned damages, slippage of upstream and downstream faces, longitudinal or latitudinal cracks and liquefaction of saturated sands are more prevalent. Slippage of upstream and downstream faces occurs when shear stress imposed on a slippage surface by earthquake is more than shear resistance of the soil. Longitudinal cracks occurring in crest and upstream parts are caused by transverse vibrations and imbalanced subsidence between core and shell; whereas latitudinal cracks formed at contact area between dam with abutment are caused by longitudinal vibrations and difference between dam's and abutment's vibration properties. Latitudinal crack risk 
stems from the fact that if they reach the impermeable core, they cause dam failure. During seismic shake, loose gravels (relative density of 0.5 and less) tend to become compact. Pore water pressure is not easily excluded until compactness occurs; thus the stress is transferred to the water and pore water pressure is increased and hence, effective pressure among soil grains is decreased. Sand, which is a friction material, loses its resistance as a result of reduced effective stress among the grains and forms a dense gain fluid and begins to move. This movement lasts until steady-state resistance of soil is lower than existing stress is due to redistribution of the stresses. Seed et al studied a number of embankment dams damaged by earthquake and concluded that:

1. Hydraulic type dams are vulnerable to failure during earthquake thought they can tolerate middle earthquakes with $0.2 \mathrm{~g}$ acceleration and magnitude of 6.5 Richter is they are constructed with suitable slope and over an appropriate foundation.

2. The major cause of dykes' destruction is reduction of shear resistance due to development of pore water pressure.

3. Completely destroyed dams had saturated sand shell or foundation.

4. Well established dams tolerated earthquakes with average and maximum acceleration of $0.2 \mathrm{~g}$ without any damage.

5. Rock fill dams with concrete upstream dyke are stable against severe earthquakes with minor deformations.

Despite promising performance of well-constructed dams during middle earthquakes, their behavior during strong seismic shake needs further investigation.

Newmark (1965) proposed sliding block method and calculated permanent deformations of sliding surfaces. In this method which assumes rigidity - perfect plasticity for soil behavior, yield acceleration of the hypothetical sliding surface is estimated at first. Then sliding potential mass is modeled to rigid block that moves only in one direction over the horizontal level; movement equations are written and permanent deformations are estimated by double integration. Due to its simplicity and applicability, the method is still used by engineers and researchers (Finn, 1995). By development of finite components methodology and its application in slope analysis, a fundamental change was made in analytical methods. For the first time Clough and Chopra (1966) calculated dam response to Elcentro earthquake records using this method and assuming homogenous viscoelastic behavior of the dam history.

Makdisi and Seed (1987) analyzed some dams using Quad4 program and estimated permanent deformations of sliding surface by investigating block movement on sloping surface (according to Newmark's method) (Makdisi \& Seed, 1987). The results were presented as normalized graphs so that deformation magnitude can be achieved by estimation of maximum acceleration at crest area and according to the height of sliding surface. Since Quad4 makes linear analysis and ignores development of pore water pressure, their results are not easily generalizable. Moreover, the graphs are old and prepared for limited earthquakes, the results require reconsideration. Martinez and Bielak (1980) proposed a numerical method for embankment dams containing a symmetry plate perpendicular to longitudinal axis of the dam which overcomes the cost of 3D finite components analysis. The authors neglected longitudinal deformations (indeed, secondary deformations) and analyzed the central section of the dam that is symmetry place using finite components methodology. Then, inertia forces and movements along 
the length axis were extended using Fourier series and the problem can be solved by 2D finite components analysis (Gazets, 1985).

Abdel - Ghahhar and Koh (1982) proposed a semi-analytical 3D method. This method can be applied to dams constructed in valleys with every shape but requires a symmetry plate. This approach is based on the method proposed by Rayleigh-Ritz and uses modal forms of shear beam or single sine functions (Abdel-Ghaffar, 1982). By an appropriate mapping, valley geometry can be converted to a cube. The results are presented natural frequencies and modal forms for embankment dams in trapezius valley. A major advantage of this method is its simplicity which is presented under more real conditions based on non-linear and non-elastic behavior of the dams and considering pore water pressure in rectangular valley.

Today, numerical methods are widely used in analyses in which, complex equations related to interaction between water and solid soil can be analyzed using advanced behavioral models (Earthquake Analysis for Dams 1986). Acceleration spectra of interested earthquakes can be used in the analysis to define entering movement of the earth. The major advantage of available numerical methods is presentation of stress fields and translocation in every part and element of the model. Other advantage of numerical method is prediction of pore water pressure variation during irregular loading cycles of the earthquake that is effective in anticipating liquefaction phenomenon in the dams. . Protection, retention and permanent evaluation of dam's stability is of great importance. Since increased safety of dam is always accompanies with increased cost, it is necessary to ensure dam stability through designing, implanting and exploiting steps and in events such as earthquake as well.

Considering he long history of dam construction in Iran, this country is one of pioneers in dam construction. More than 50 dams, constructed between 500BC and 1800, have been identified in Iran based on historical records. For example, Iranian dam construction masters developed a new method in dam construction by horizontal curving of dam body knowing arch properties and its loading way and thus, invention of arch dams can be attributed to Iranians.

\section{Software description}

There are a number of analytical software in the field of embankment dams and geotechnical studies that can be used in this projects (GEO, Plaxis, FLAC, etc). One of well-known software is FLAC that is described in this section (ITASCA Consulting Group 2001). FLAC (Fast Lagrangian Analysis of continua in 2D) is a finite difference program that is widely used for fast Lagrangian analysis of $2 \mathrm{D}$ continua. The software models constructs' behavior in which soil, stone and other materials that reach plasticity after yield threshold. FLAC was originally designed for mine and geotechnic engineers but is widely used for solving complicated mechanical problems in other engineering fields due to its numerous capabilities. Behavioral models defined in this software enable the engineers to model and analyze various problems by non-linear analyses. The attributes of the software are presented in figure 1. 


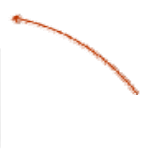

Figure1-Software properties

FLAC represents an explicit, finite difference method that acts based on Lagrange analysis. Typical calculation cycle of the software is depicted in the figure below. In this method, motion equations are first used to extract new speeds and translocations caused by forces and tresses. Then yield rates are estimated according to velocity values and new stress values are calculated based on new yield rates. Calculation cycle of FLAC software is depicted in graph 1.

Each cycle occurs in a time frame. It should be mentioned that in every operator depicted this graph, all variations of the zones occur in relation to preceding step. For example, lower operator takes the estimated speed and calculates new stress values for each element. Since there is no need for formation of stiffness matrix, coordinates of each point are updated in every timeframe for large strain. The newly formed relocations are added to previous coordination. Thus the relocated elements and model geometry are changed. This calculation method is called Lagrangian formulation. The opposite of this formulation is Euler formulation in which, deformations are calculated according to primary fixed elements. Euler formulation has better performance where strain values are relatively small. In FLAC, the modeled environment is divided into a finite difference mesh network with quadrilateral elements. FLAC automatically divided each element into two triangular elements where strain is fixed through the range. Software elements are presented in figure 2 . 


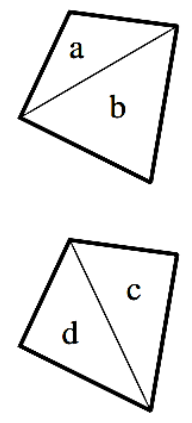

(a)



(b)

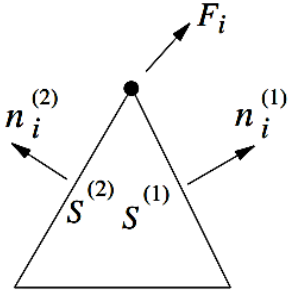

(c)

Figure 2- a) Quadrilateral elements used in FLAC; b)Typical triangular element together with velocity vectors; c) Typical triangular element together with node force vector and stress tensors

As seen, force, speed and translocation vectors are exerted to vertices of the triangular sub-element while stress tensors are exerted to surfaces of the sub-elements. If geometrical shape of a certain triangular element is not as large as others, FLAC assigns the main element for that area and avoids generation of quadrilateral element with two triangular sub-elements. If there is no logical proportion between the sides of the two sub-elements, an Error message appears in FLAC. FLAC enables the user to perform dynamical analysis on the model in $2 \mathrm{D}$, plate strain and axial symmetry continua. Moreover, dynamic analysis can be performed on the models composed of construct elements and hence, the user can study construct-soil interaction. Dynamic analysis can be used to model earthquake, vibrating foundations, explosion, and so forth.

\section{Evaluating embankment dams' stability}

Although vulnerability of embankment dams is not a new issue, behavioral complexity of such constructs makes it necessary to conduct more sophisticated studies with stronger instruments. Static behavior of embankment dams has been the focus of interest among scholars, designers and project managers. Moreover, since most of embankment dams constructed in Iran are older than ten years, thus their static stability should be evaluated accurately.

3-1-Specification of behavioral model and designing parameters of dam materials

Mohr-Coulomb was used as behavioral model in this study. The reasons for this choice include the match between the model and behaviors of materials such as sand, gravel and concrete (Vermeer \& Borst, 1984), its popularity among civil engineers and its good alignment with FLAC software. Parameters used in this model include adhesion, friction angle, bulk modulus, shear modulus and tensile strength. The parameter value is zero if the parameter is not used. It should mentioned that the software suggested application bulk modulus $(\mathrm{K})$ and shear modulus $(\mathrm{G})$ instead of Young modulus (E) and Poisson coefficient that is due to better convergence of the software with these parameters (ITASCA Consulting Group 2001). When it is necessary to investigate fluid impact, 
other parameters such as permeability and porosity should be considered. Properties of the materials used (calibrated) in the dam according to the selected section are presented in table 2 and figure 5.

Table2. Parameters of dam materials

\begin{tabular}{|c|c|c|c|c|c|c|c|}
\hline $\begin{array}{l}\text { Material } \\
\text { type }\end{array}$ & $\gamma\left(\frac{k N}{m^{3}}\right)$ & $k\left(\frac{c m}{s}\right)$ & $E(M P a)$ & $v$ & $\varphi\left({ }^{\circ}\right)$ & $c^{\prime}(k P a)$ & $\begin{array}{l}\text { Behavioral } \\
\text { model }\end{array}$ \\
\hline Core & 2100 & $5 e-7$ & 10 & 0.35 & 25 & 40 & $\begin{array}{l}\text { Mohr- } \\
\text { Coulomb }\end{array}$ \\
\hline Shell & 2500 & $3.5 e-4$ & 45 & 0.3 & 40 & - & $\begin{array}{l}\text { Mohr- } \\
\text { Coulomb }\end{array}$ \\
\hline Foundation & 2400 & $5 e-6$ & 200 & 0.25 & - & - & Elastic \\
\hline Filter & 2250 & $6 e-4$ & 40 & 0.3 & 38 & - & $\begin{array}{l}\text { Mohr- } \\
\text { Coulomb }\end{array}$ \\
\hline
\end{tabular}

According to software recommendations and in order to prevent from instability and model failure in reaching balance, details of dam and dam's filter-due to similarity with the shell- were ignored.

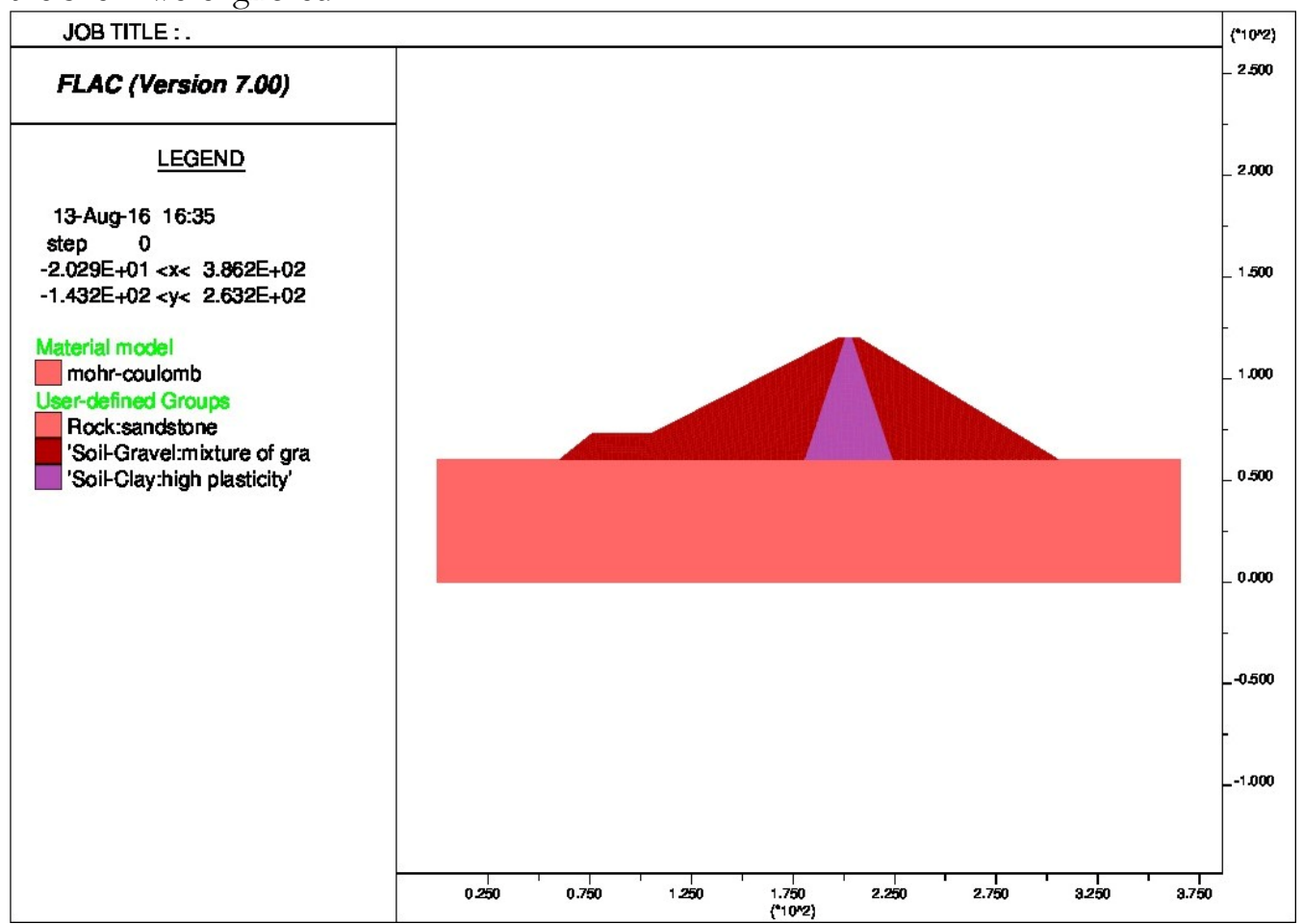

Figure 3. Specification of dam's materials 


\subsection{Dam components}

\subsubsection{Reservoir}

Volume up to normal level: $5.9 \times 10^{6} \mathrm{~m}^{3}$

Useful volume: $5.8 \times 10^{6} \mathrm{~m}^{3}$

Length, width and area of lake: $150 \mathrm{~m}, 210 \mathrm{~m}$ and 32 hectares

\subsubsection{Dam body}

Type: gravel with impermeable clay core

Crest level: $1892 \mathrm{~m}$ above free sea surface

Bed level in the axis place: $1833 \mathrm{~m}$ from sea surface

Dam height from river bed: $59 \mathrm{~m}$

Maximum height from foundation: $60 \mathrm{~m}$

Crest length: $177 \mathrm{~m}$

Crest width: $10 \mathrm{~m}$

Width of foundation: $235 \mathrm{~m}$

Embankment body size: $560000 \mathrm{~m}^{3}$

\subsubsection{Spillway}

Type: free lateral placed in right abutment

Threshold: concrete, peak shape

Elevation of approach channel bottom: $1885 \mathrm{~m}$

Length of approach channel: $50 \mathrm{~m}$

Elevation of spillway threshold: $1887.60 \mathrm{~m}$

Threshold length: $32 \mathrm{~m}$

Capacity: $400 \mathrm{~m}^{3} / \mathrm{s}$

Rapids' length, with and slope: $162 \mathrm{~m}, 10 \mathrm{~m}$ and 9-45.6\%

Energy dissipation system: flip bucket with curvature radius of $8 \mathrm{~m}$

\section{Evaluation of dam foundations" stability and performance}

Since model compatibility with real condition should be confirmed before any analysis, primary parameters were scrutinized according to the results of accurate instruments and then the final model was evaluated. The results obtained from experiments on core and shell materials including grain composition, direct shear, uniaxial, triaxial and compactness were used and primary parameters of the materials were obtained from technical reports. In calibration step, primary parameters were specified for the dam and the input parameters were scrutinized via comparing the data obtained from the software with those achieved by recording tool. Water flow and mechanical analysis should be evaluated individually. Dam foundation monitoring was provided by study of the history for various heights to achieve both system balance and comparison with accurate tools. Four latitudinal sections were predicted as instrumenting sections. The sections were chosen according to diversity and heterogeneity of dam regarding permeability and subsidence. Sections' properties are presented in figures 6-9. Out of these sections, section 1 is located in left abutment, section 4 in right abutment, section 3 in deviation gallery and section 2 in river bed. 


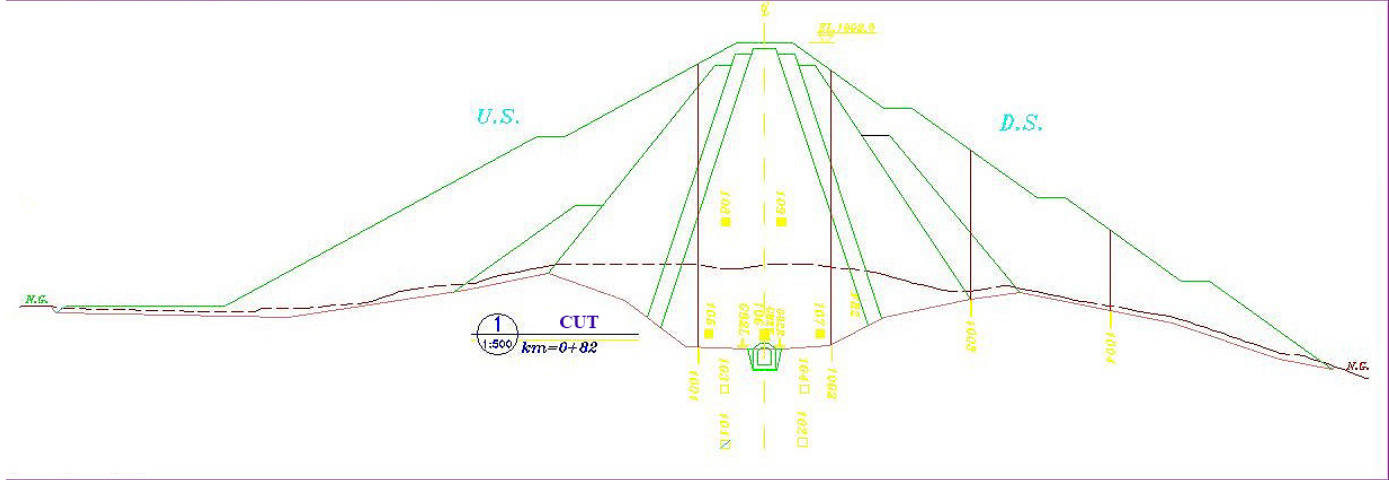

Figure 4. Dam's section1

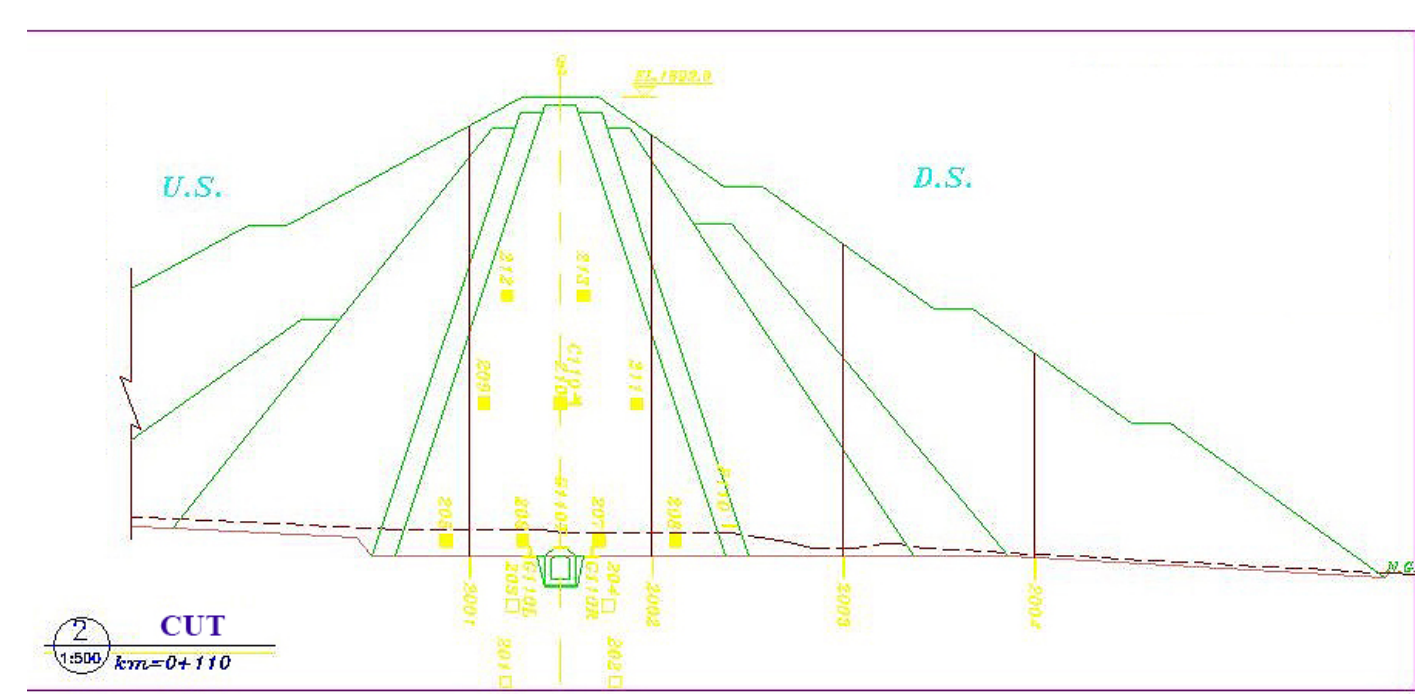

Figure 5. Dam's section2

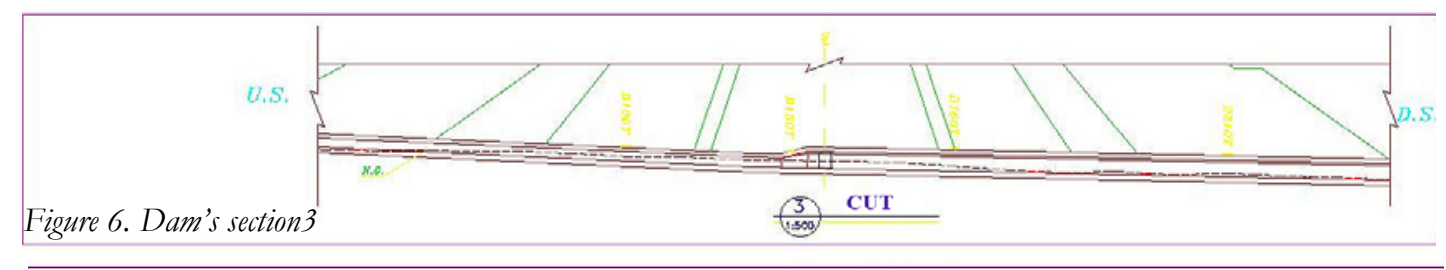

Figure 6. Dam's section3

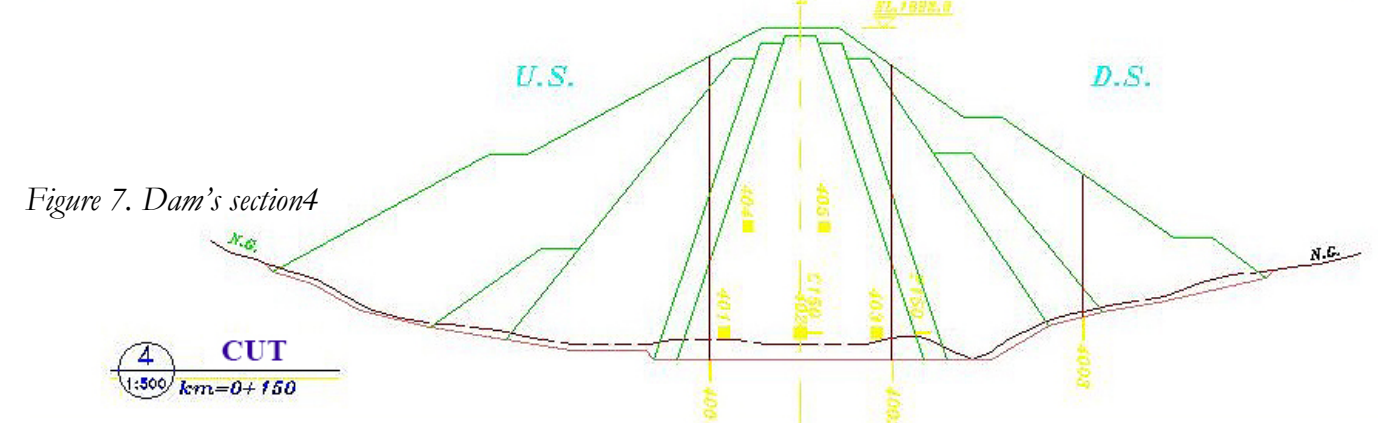

Published by ECSDEV, Via dei Fiori, 34, 00172, Rome, Italy 
Base status of dam hydrology was evaluated by Piezometric well. Observation and evaluation of underground water level before and after watering to determine the variation in percolation pattern and the resulting consequences in exploiting season is a powerful tool to evaluate unusual phenomena such as over watering, erosion of natural materials or erosion of materials used in impermeable part of the dam body. In order to control sealing performance of dam foundation, a number of vibrating piezometers with special filter and low airing value were predicted in both sides of grout curtain and two different levels of foundation rock in predefined areas. Due to high permeability of the filter in these piezometers, necessary measures were provided to prevent from leaching of small gains and filter obstruction.

\section{Vibrating wire piezometers}

Vibrating wire piezometers (PW) of PWF type manufactured by Roctest Telemac Company were used for installation and run in borehole. Two manual reading devices called MB-6T/6TL were purchased from the company for data recording.

5 -1- Results of data reading and processing

Results of readings were analyzed using a number of tables and graphs to propose the evaluation of behavioral study.

\section{Vibrating wire piezometers of foundation}

In order to evaluate variation of pore water pressure in dam foundation, eight wire piezometers were installed at two sections 1 and 2 and each section, four piezometers were installed. In every section, two piezometers were installed upstream of dam axis and two were installed in downstream. Installation level of the piezometers in section 1 was 3 and 13 meters and in section 2 was 8 and 18 meters below river bed level in dam location. Results of piezometer reading in sections 1 and 2 and in combination with lake level variation are presented in graphs 2 and 3. According to these graphs and based on foundation piezometers behavior as presented in table 3 and 4, piezometer behavior in each section is presented individually.

Table 3. Evaluation of electrical piezometers' behavior of the foundation at section 1

\begin{tabular}{|l|l|l|}
\hline Maximum piezometer level & $\operatorname{Pmax}(\mathrm{KPa})$ & Instrument \\
\hline 1854.55 & 339 & V82-U7.10-1820.4 \\
\hline 1839.98 & 196.1 & V82-D7.10-1820.4 \\
\hline 1864.53 & 338.75 & V82-U7.38-1830 \\
\hline 1836.74 & 85.85 & V82-D7.3-1830 \\
\hline
\end{tabular}

Table 4. Evaluation of electrical piezometers' behavior of the foundation at section 2

\begin{tabular}{|l|l|l|}
\hline Maximum piezometer level & $\operatorname{Pmax}(\mathrm{KPa})$ & Instrument \\
\hline 1852.40 & 357.12 & V110-U7.39-1815.75 \\
\hline 1845.23 & 283.69 & V110-D7.39-1815.75 \\
\hline 1852.68 & 261.73 & V82-U6.34-1825.7 \\
\hline 1843.99 & 176.48 & V82-D6.34-1825.7 \\
\hline
\end{tabular}




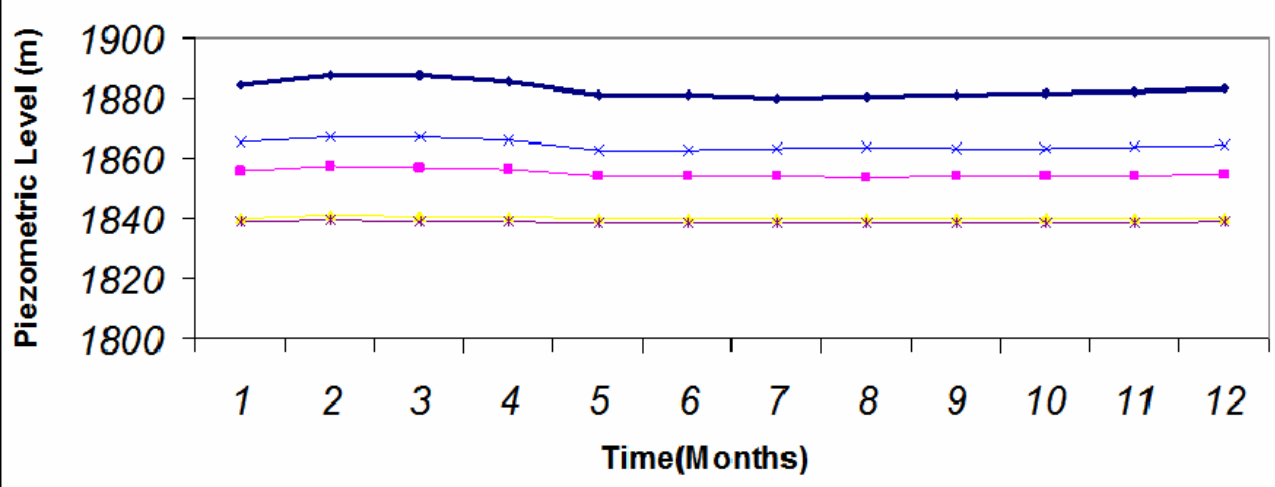

$\rightarrow$ res level $\rightarrow 101-102 \div 103 \quad * 104$

Graph2. Results of piezometer level reading at section 1

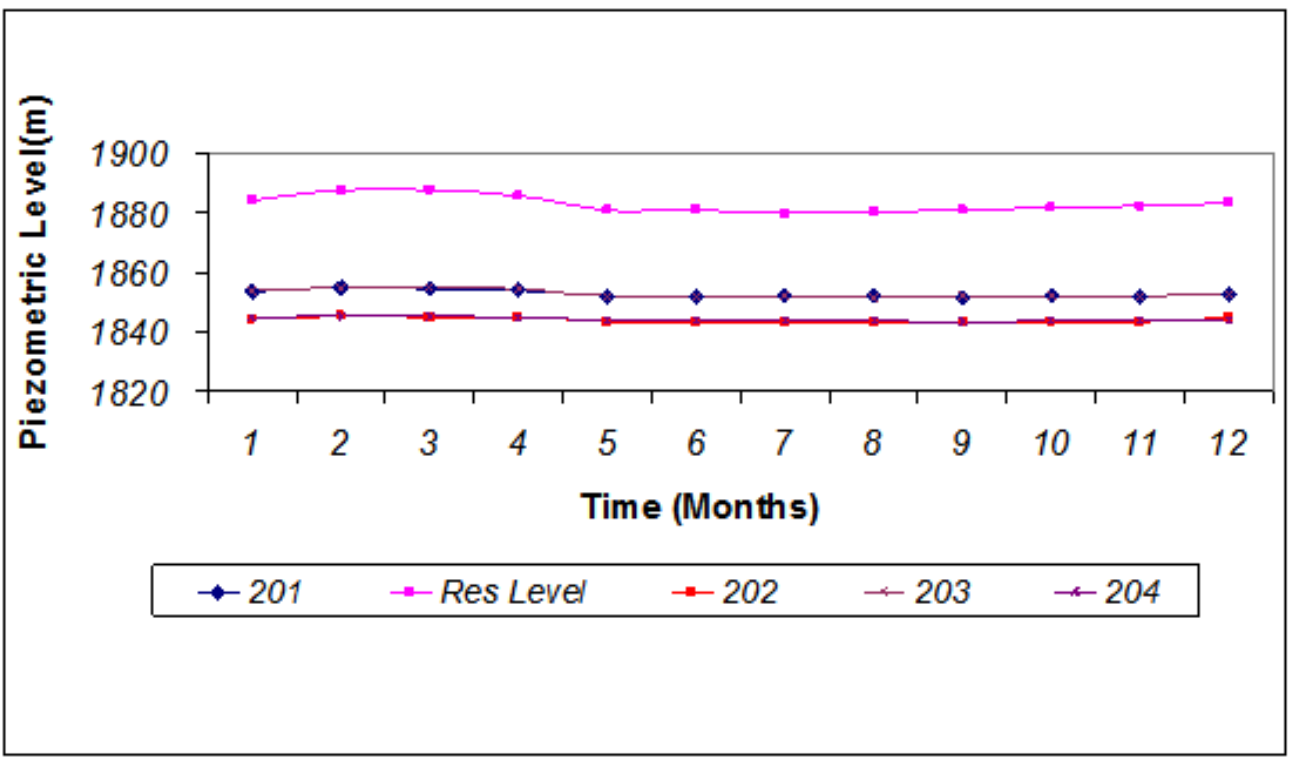

Graph3. Results of piezometer level reading at section 2

\section{Vibrating wire piezometers in section 1}

According to the results obtained by drawing the graphs of four piezometers installed in foundation, performance of piezometers in section 1 can evaluated as follows:

Maximum piezometer level was about $1864.53 \mathrm{~m}$ which was 18.5 below the maximum lake level at the same time. Pressure of all piezometers in this section follows lake level variation. 
Maximum pressure in upstream piezometers was about 339 which is 142.9 unit higher than that of piezometers installed downstream.

Grout curtain performance in terms of piezometer level drop can be seen by moving downward; the value of this drop was 14.30 and 25.29 in two installation levels of 1820.4 and 1830 .

\section{Vibrating wire piezometers in section 2}

According to the results obtained by drawing the graphs of four piezometers installed in foundation, performance of piezometers in section 2 can evaluated as follows:

Maximum piezometer level was about $1855.13 \mathrm{~m}$ which was 32.47 below the maximum lake level at the same time. Pressure of all piezometers in this section follows lake level variation.

Maximum pressure in upstream piezometers was higher than that of downstream piezometers; the difference was $7.17 \mathrm{~m}$ and 8.25 in levels of 1815.75 and 1825.7; respectively.

Grout curtain performance in terms of piezometer level drop can be seen from upstream to downstream; the value of this drop was 7.17 and 8.25 in two installation levels of 1815.75 and 1825.7.

\section{Vibrating wire piezometers in the dam body} follows:

Eighteen wire piezometers were installed at three sections in the dam body as

Section 1 (left): three piezometers in 1840 level and two in 1860 level

Section 2 (middle): four piezometers in 1834 level, three piezometers in 1852 level and two in 1866 level

Section 4 (right): three piezometers in 1852 level and two in 1866 level

For better evaluation of dam's body piezometers performance, a set of integrated graphs were drawn for piezometers of each level by integrating individual graphs depicting piezometric level variation against time. Thus, dam body behavior could be evaluated as described below.

\subsection{Vibrating wire piezometers in the dam body, section 1}

The results of piezometer reading at section 1 are presented in table 5 . The most notable behavior was:

Piezometers at 1840 level:

Piezometer installed upstream of this level followed lake level variation and recorded the highest pressure equal to $310.10 \mathrm{KPa}$.

The remaining two piezometers didn't show considerable variation in relation to water level 
Table5. Results of processing of electrical piezometer reading of dam body at section 1

\begin{tabular}{|c|c|c|c|c|c|}
\hline \multirow[t]{2}{*}{ Description } & \multicolumn{2}{|c|}{ Results of report period } & \multirow{2}{*}{\begin{tabular}{|l|} 
Maximum \\
pressure of \\
the dam in \\
2004
\end{tabular}} & \multirow[t]{2}{*}{ Instrument } & \multirow[t]{2}{*}{ Row } \\
\hline & \begin{tabular}{|l|} 
Maximum \\
piezometer \\
level
\end{tabular} & \begin{tabular}{|l|} 
Maximum \\
pressure
\end{tabular} & & & \\
\hline Follows variation of lake level & 1871.61 & 310.10 & 206.39 & 105 & 1 \\
\hline Follows variation of lake level with delay & 1847.87 & 77.18 & 125.67 & 106 & 2 \\
\hline Follows variation of lake level with delay & 1852.54 & 123.03 & 220.21 & 107 & 3 \\
\hline Follows variation of lake level & 1877.26 & 169.28 & 66.09 & 108 & 4 \\
\hline Follows variation of lake level with delay & 1882.49 & 122.53 & 139.58 & 109 & 5 \\
\hline
\end{tabular}

Piezometers at 1860 level:

Piezometer installed upstream of this level didn't follow lake level variation during the first six months but followed lake level variation at the second six months.

Compared to 2004, upstream piezometer (piezometer 108) shows increase in maximum pressure which is proportional to increase in lake level.

Graphs 4 and 4 shows variation of piezometric level at codes 1840 and 1860

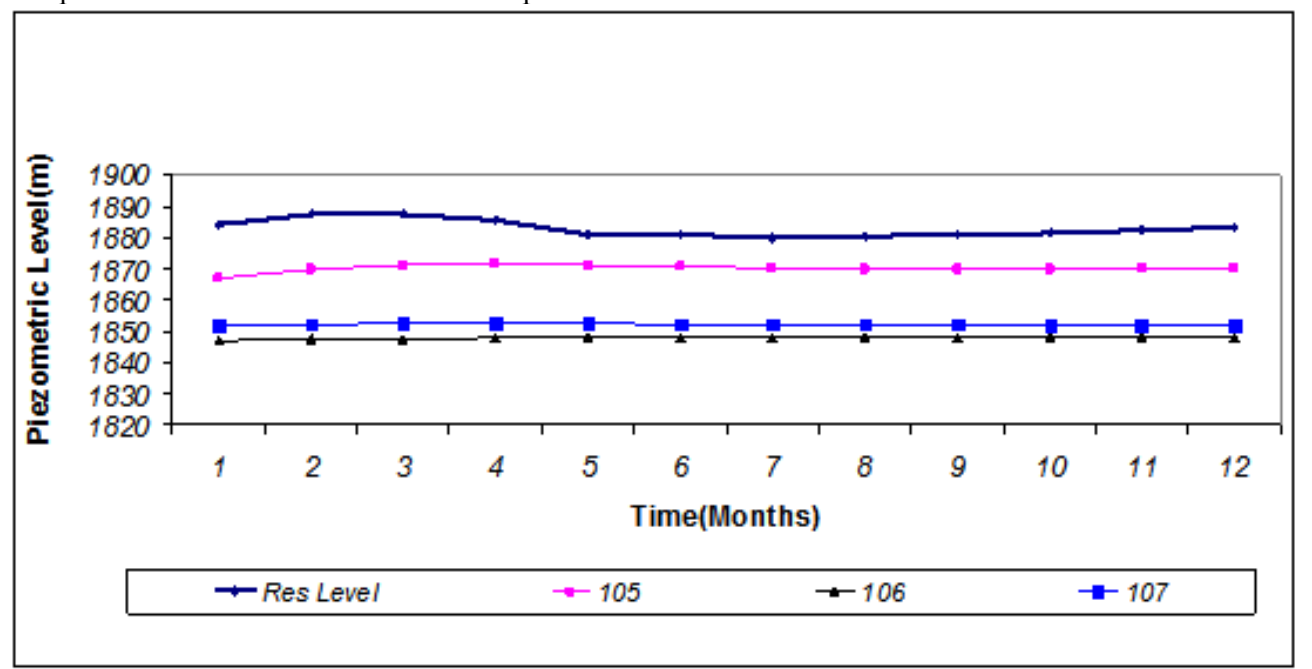

Graph4. Variation of piezometer level at code 1840 


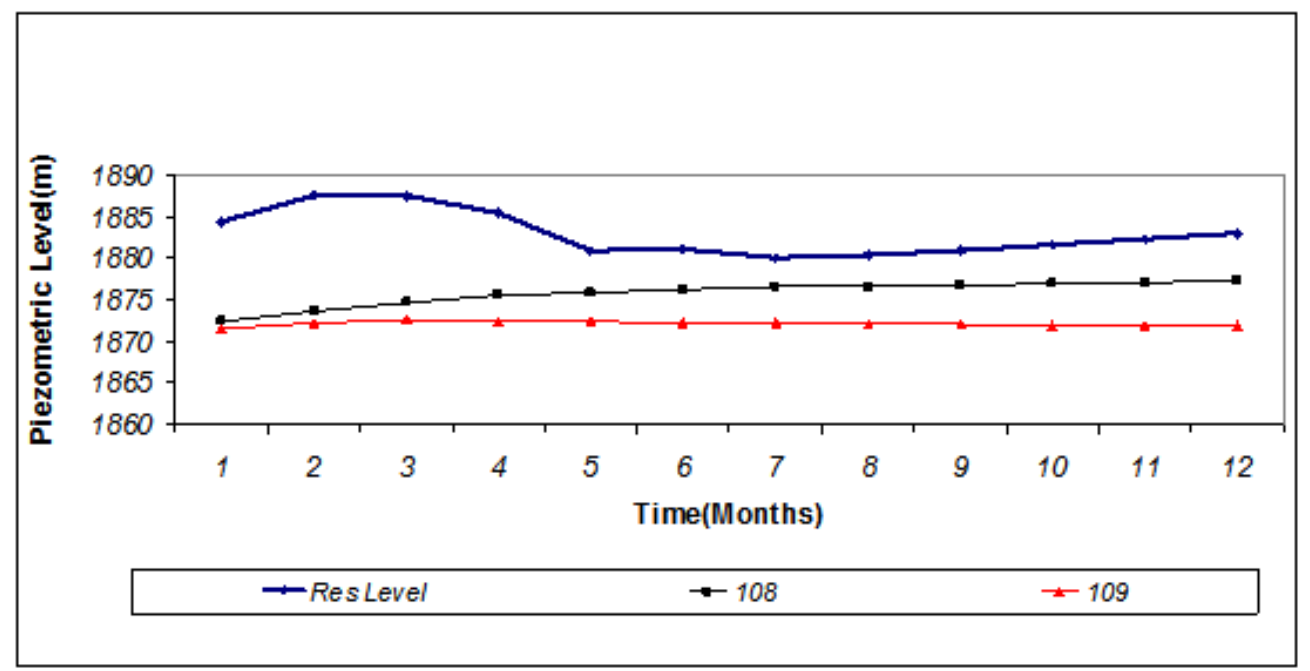

Graph5. Variation of piezometer level at code 1860

\subsection{Vibrating wire piezometers in the dam body, section 2}

The results achieved by the graphs show that:

Level 1834:

Pressure variation in two piezometers installed upstream of this level followed lake level variation so that the highest pressure recorded by piezometers coincides the highest pressure of the lake.

Two piezometers installed downstream show relatively constant pressure which is not unexpected considering core saturation and installation level.

The highest piezometric level of 1875.48 was recorded by piezometer 205 that is $41 \mathrm{~m}$ higher than its installation level.

Level 1852:

Pressure variation of the piezometers installed in this level follows lake level.

Pressure at downstream piezometer was close to zero.

Pressure variation of piezometer installed in the core follows variation of lake level with a delay.

Level 1866:

Pressure variation of the piezometers installed in this level follows lake level.

Pressure variation of downstream piezometer (213) follows general variation pattern.

Graphs 6-8 represent piezometric level variation at codes 1852, 1834 and 1866. 


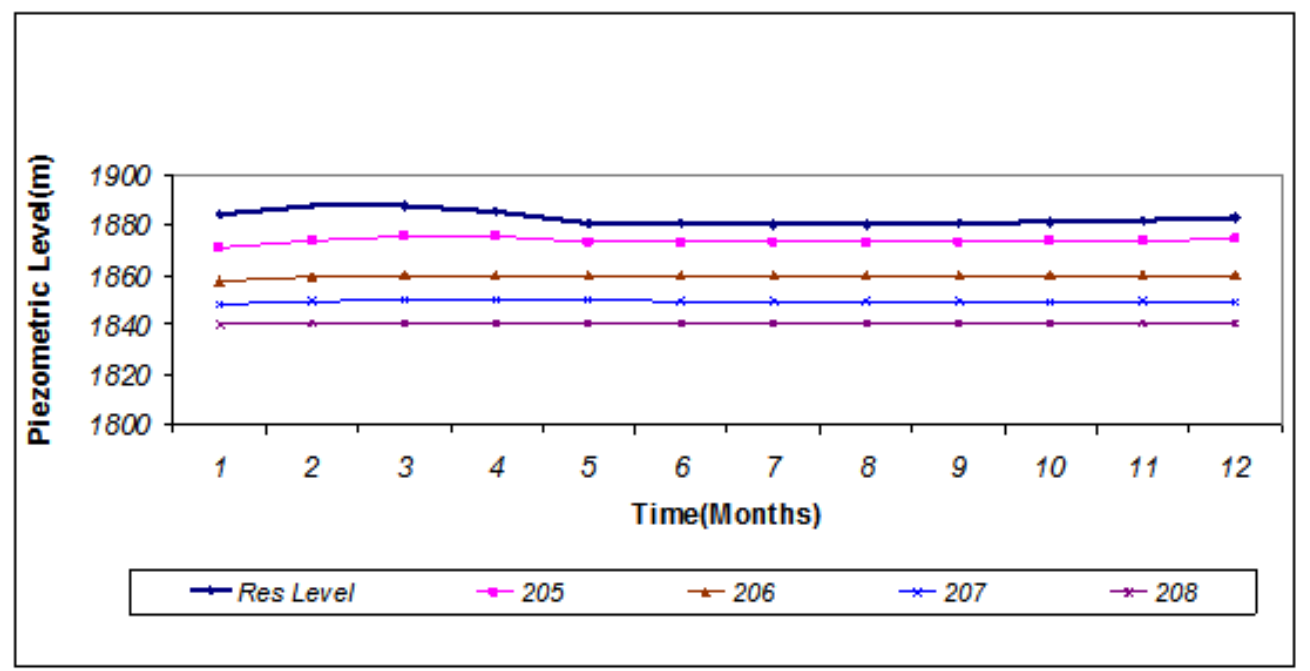

Graph6. Variation of piezometer level at code 1834

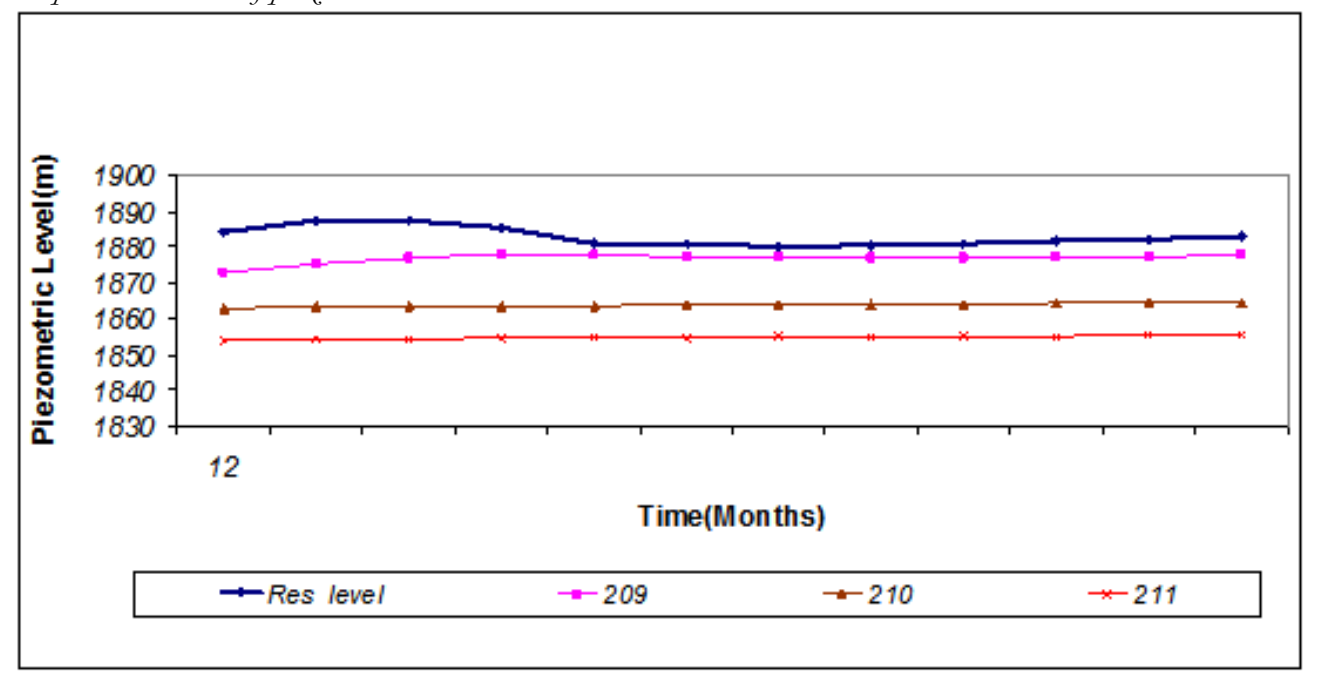

Graph7. Variation of piezometer level at code 1852 


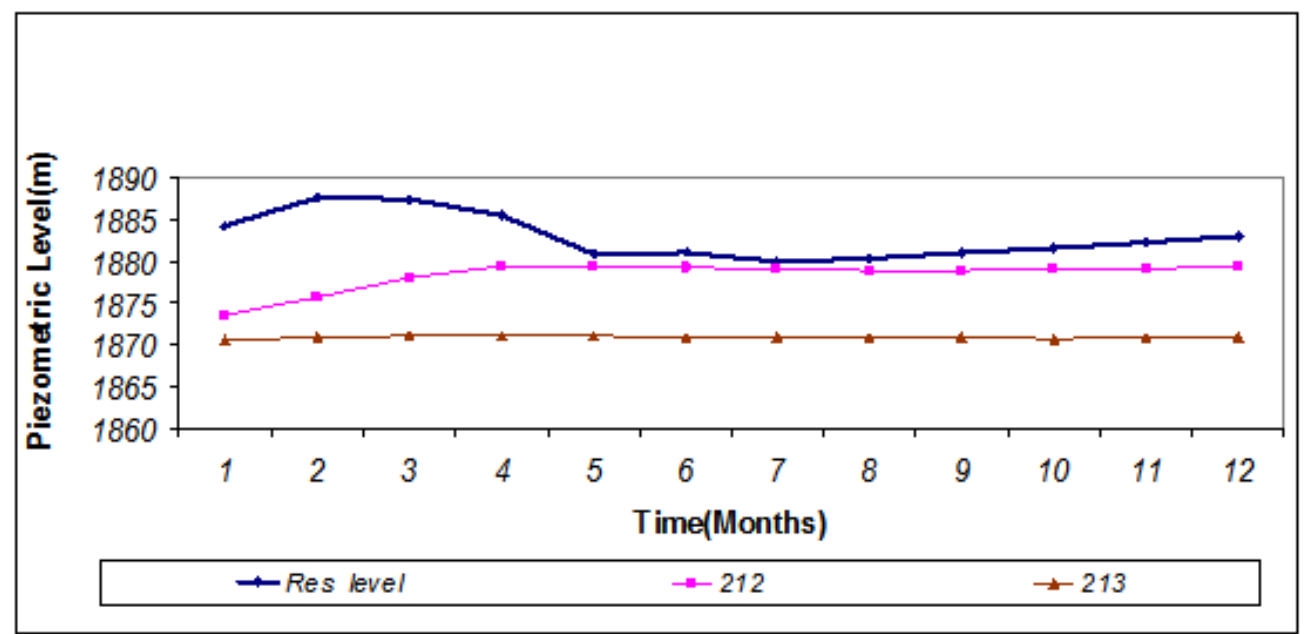

Graph8. Variation of piezometer level at code 1866

\subsection{Vibrating wire piezometers in the dam body, section 4}

Conclusion of graphs' data is presented as follows:

Level 1852:

Pressure variation in upstream and middle piezometers follows variation of lake level; whereas a gradual drop in pressure of downstream piezometer (403) was observed without following lake level.

The highest pressure value was recorded by piezometer 401 installed in clay core.

Level 1866:

Pressure variation in piezometer 404 follows variation of lake level with a 3-month delay while no variation was observed in piezometer 405.

Graphs 9-10 represent piezometric level variation at codes 1852 and 1866.

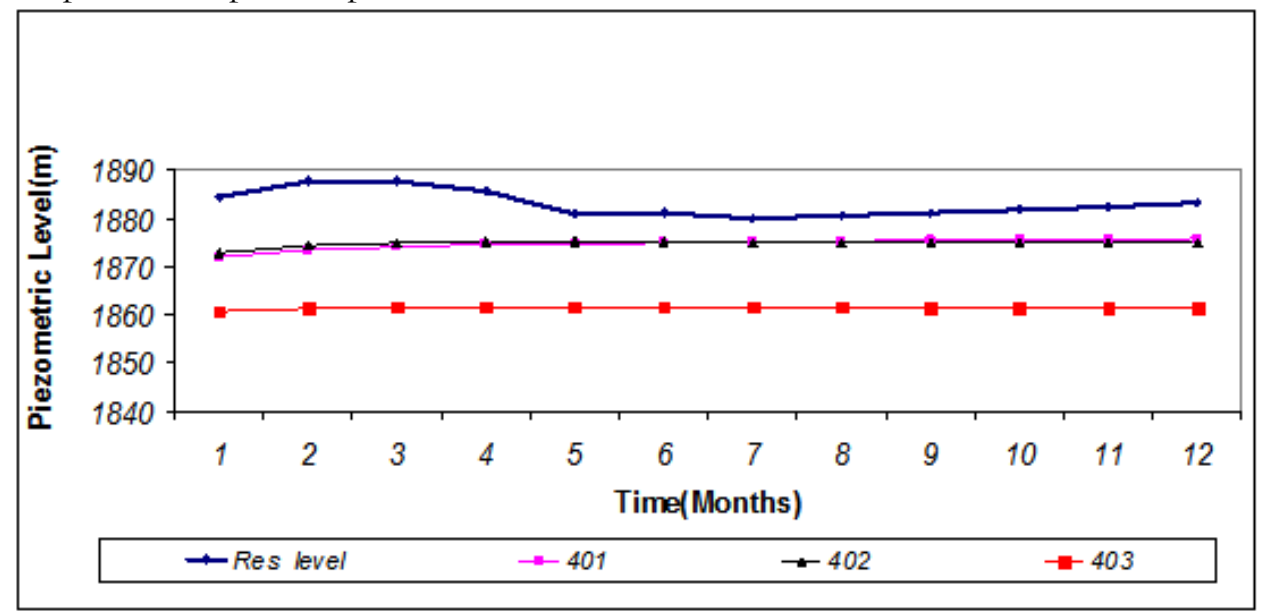

Graph9. Variation of piezometer level at code 1852 


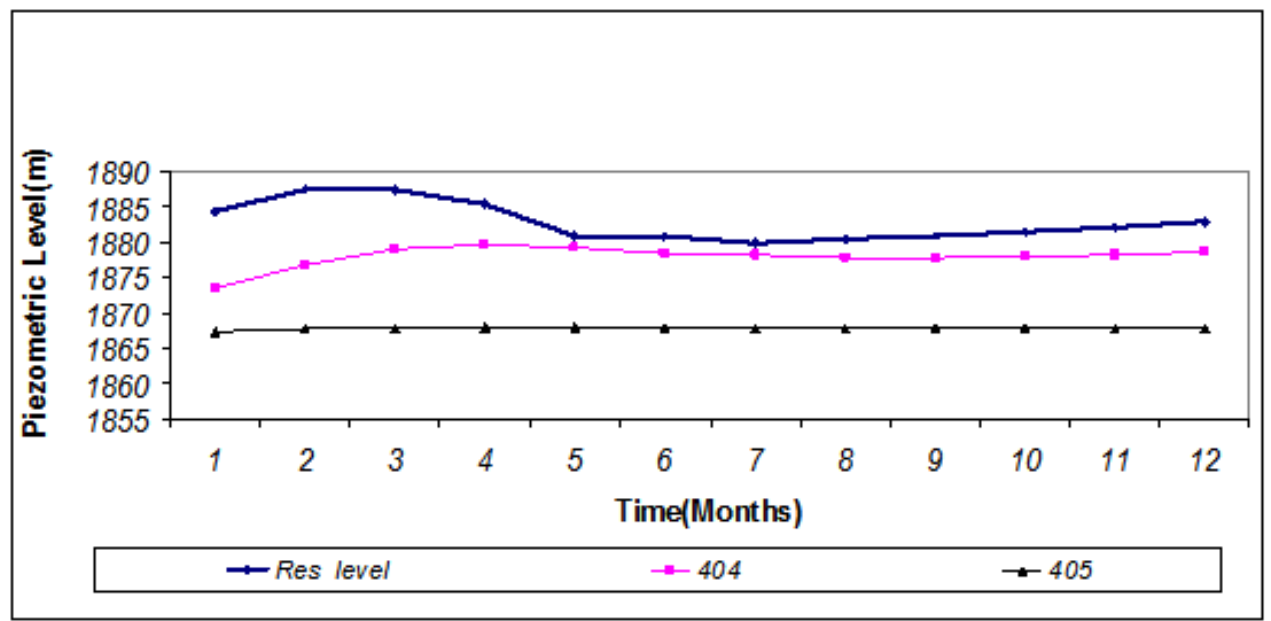

Graph10. Variation of piezometer level at code 1866

\section{Comparison of pore water pressure with accurate tools data}

Since the main goal of this research was to reach pre-earthquake condition, calibration of pre-earthquake pressures of software with pore water pressure read by piezometers is of great importance. Thus, this section deals with this issue. Piezometers were installed in dam body as depicted in section 2 .

\subsection{Comparison of piezometers at height code of 1834}

Table 6 represents comparison of piezometers at level 1834 and graph 11 shows pore water pressure at this level.

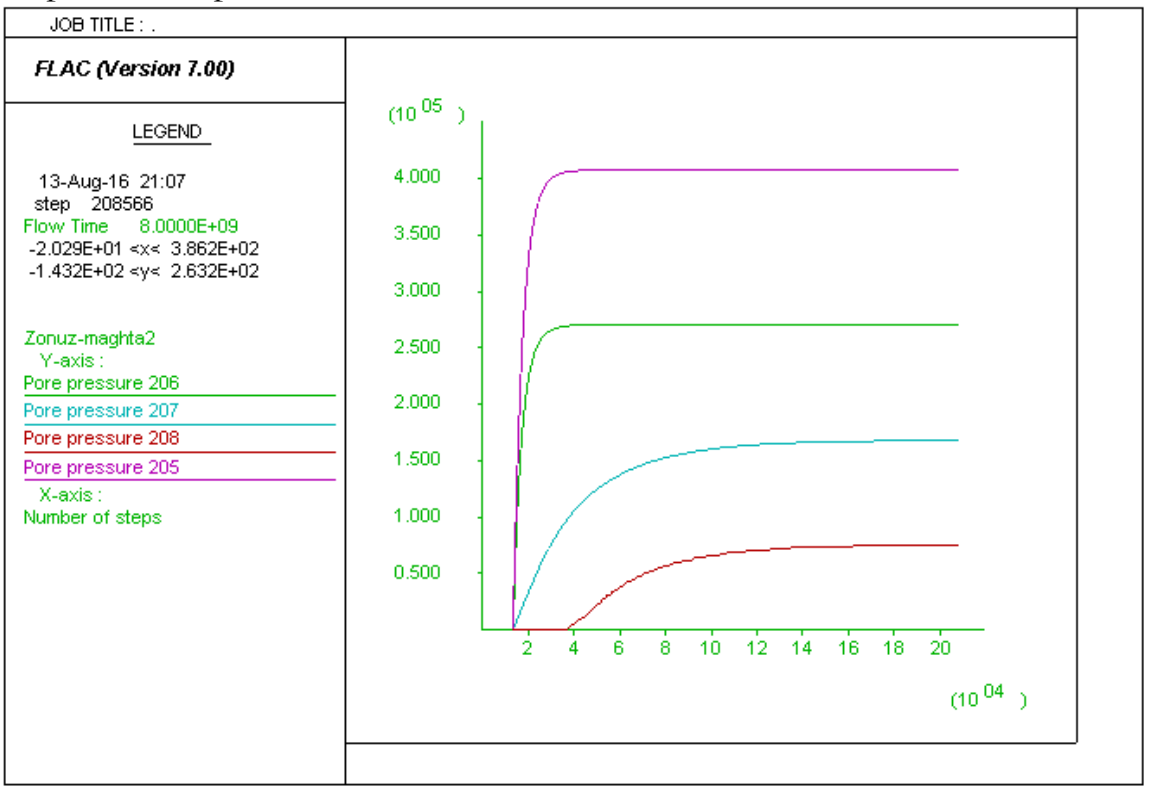

Graph11- Pore water pressure at the place of 1834 level piezometers of the sections of two dams 
Table6. Comparison of piezometers of 1834 level

\begin{tabular}{|l|l|l|l|l|}
\hline $\begin{array}{l}\text { Difference } \\
(\%)\end{array}$ & $\begin{array}{l}\text { Piezometric level of the } \\
\text { software }\end{array}$ & $\begin{array}{l}\text { Piezometric level } \\
\text { of the instrument }\end{array}$ & $\begin{array}{l}\text { Installation } \\
\text { height }\end{array}$ & $\begin{array}{l}\text { Piezometer } \\
\text { umber }\end{array}$ \\
\hline & $1834+41=1875(\mathrm{~m})$ & $1876 \mathrm{~m}$ & $1834 \mathrm{~m}$ & 205 \\
\hline & $1834+27.1=1861.1(\mathrm{~m})$ & $1861 \mathrm{~m}$ & $1834 \mathrm{~m}$ & 206 \\
\hline $1834+16.7=1850.7(\mathrm{~m})$ & $1850 \mathrm{~m}$ & $1834 \mathrm{~m}$ & 207 \\
\hline & $1834+7.48=1841.48(\mathrm{~m})$ & $1841 \mathrm{~m}$ & $1834 \mathrm{~m}$ & 208 \\
\hline
\end{tabular}

According to modeling results of the level 1834 which is above the foundation, the results obtained by the software for the junction point between foundation and core is highly close to those obtained by accurate tool; suggesting accuracy of dam modeling.

\subsection{Comparison of piezometers at height code of 1852}

Table 7 represents comparison of piezometers at level 1852 and graph 12 shows pore water pressure at this level.

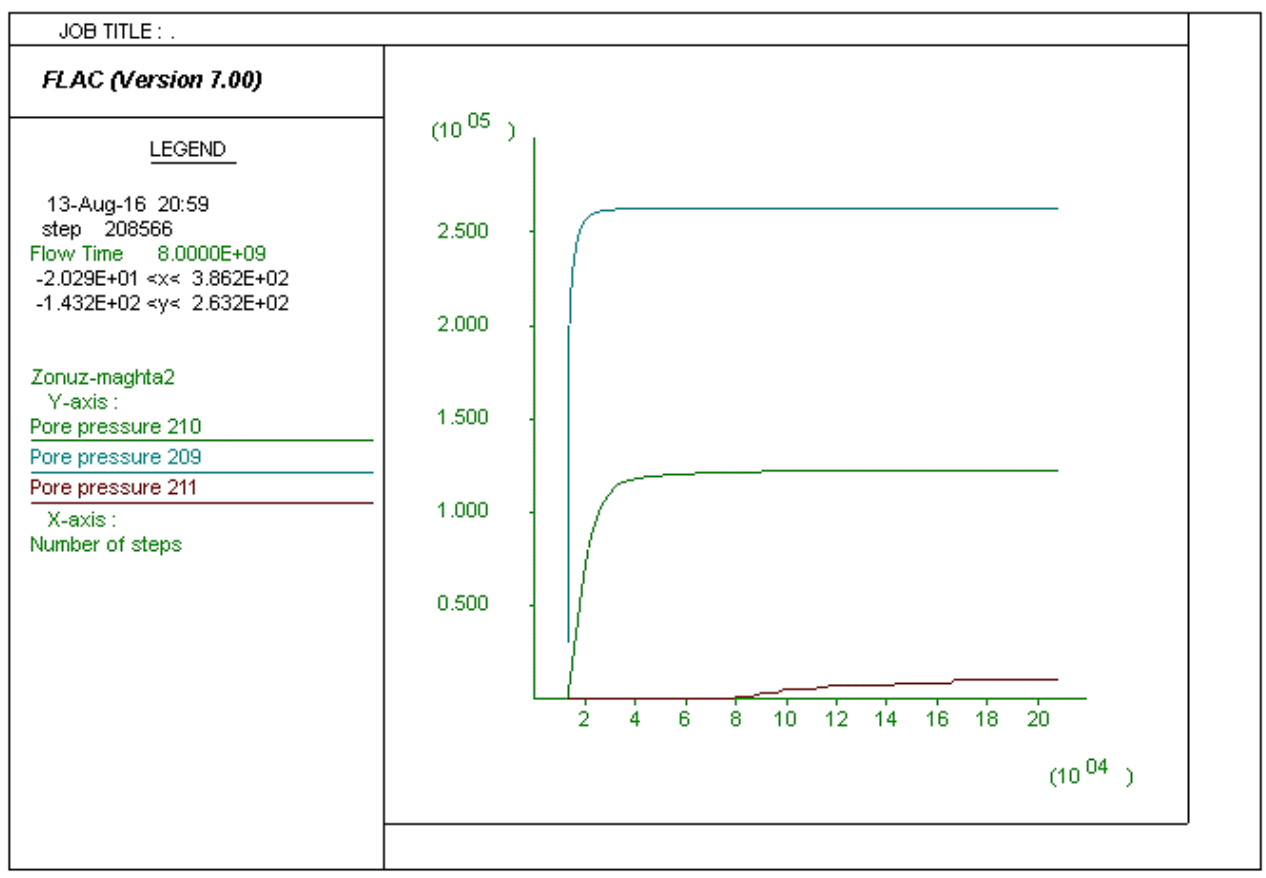

Graph12- Pore water pressure at 1852 level piezometers of the sections of two dams

Table7. Comparison of piezometers of level 1852

\begin{tabular}{|l|c|l|l|l|}
\hline $\begin{array}{l}\text { Difference } \\
(\%)\end{array}$ & Piezometric level of the software & $\begin{array}{l}\text { Piezometric level } \\
\text { of the instrument }\end{array}$ & $\begin{array}{l}\text { Installation } \\
\text { height }\end{array}$ & $\begin{array}{l}\text { Piezometer } \\
\text { umber }\end{array}$ \\
\hline & $1852+26.25=1878.25(m)$ & $1878 \mathrm{~m}$ & $1852 \mathrm{~m}$ & 209 \\
\hline & $1852+12.2=1864.2(\mathrm{~m})$ & $1864 \mathrm{~m}$ & $1852 \mathrm{~m}$ & 210 \\
\hline & $1852+1.1=1853.1(\mathrm{~m})$ & $1853.5 \mathrm{~m}$ & $1852 \mathrm{~m}$ & 211 \\
\hline
\end{tabular}


Except for piezometer 211 that has a slight difference with tool data; other piezometers fulfill the requirement of an accurate modeling. It should be mentioned that the difference of piezometer 211 is also acceptable.

\subsection{Comparison of piezometers at height code of 1866}

Table 8 represents comparison of piezometers at level 1866 and graph 13 shows pore water pressure at this level.

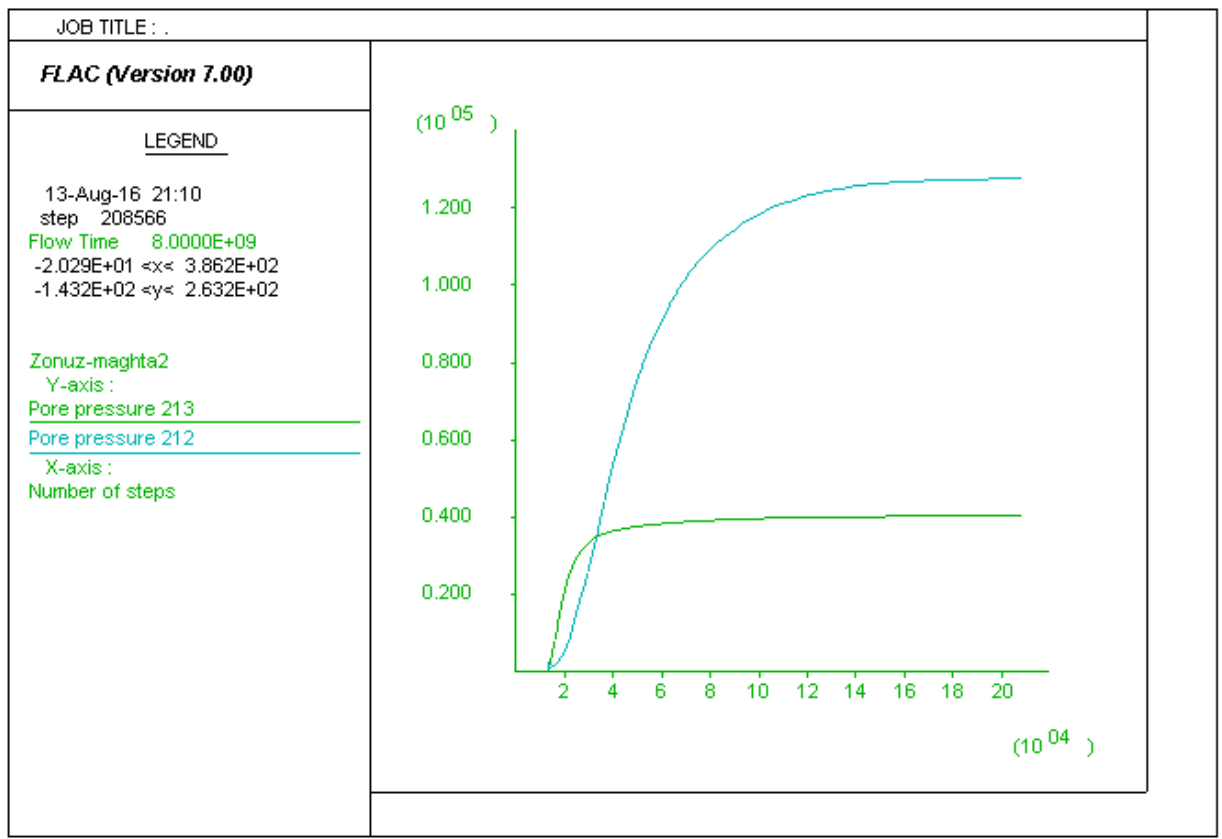

Graph13-Pore water pressure at 1866 level piezometers of the sections of two dams

Table8. Comparison of piezometers of level 1866

\begin{tabular}{|l|l|l|l|l|}
\hline $\begin{array}{l}\text { Difference } \\
(\%)\end{array}$ & $\begin{array}{l}\text { Piezometric level of the } \\
\text { software }\end{array}$ & $\begin{array}{l}\text { Piezometric level } \\
\text { of the instrument }\end{array}$ & $\begin{array}{l}\text { Installation height } \\
\begin{array}{c}1866+12.75 \\
=1878.75(m)\end{array}\end{array}$ & $\begin{array}{l}1878 \mathrm{~m} \\
\text { umber }\end{array}$ \\
\hline & $1866+4.1=1871.1(m)$ & $1870 \mathrm{~m}$ & $1866 \mathrm{~m}$ & 212 \\
\hline
\end{tabular}

The results indicate that the modeling match the real condition.

\section{Comparing piezometers of foundation}

Table 9 represents comparison of piezometers at level 1815.75 and graph 14 shows pore water pressure at this level. 


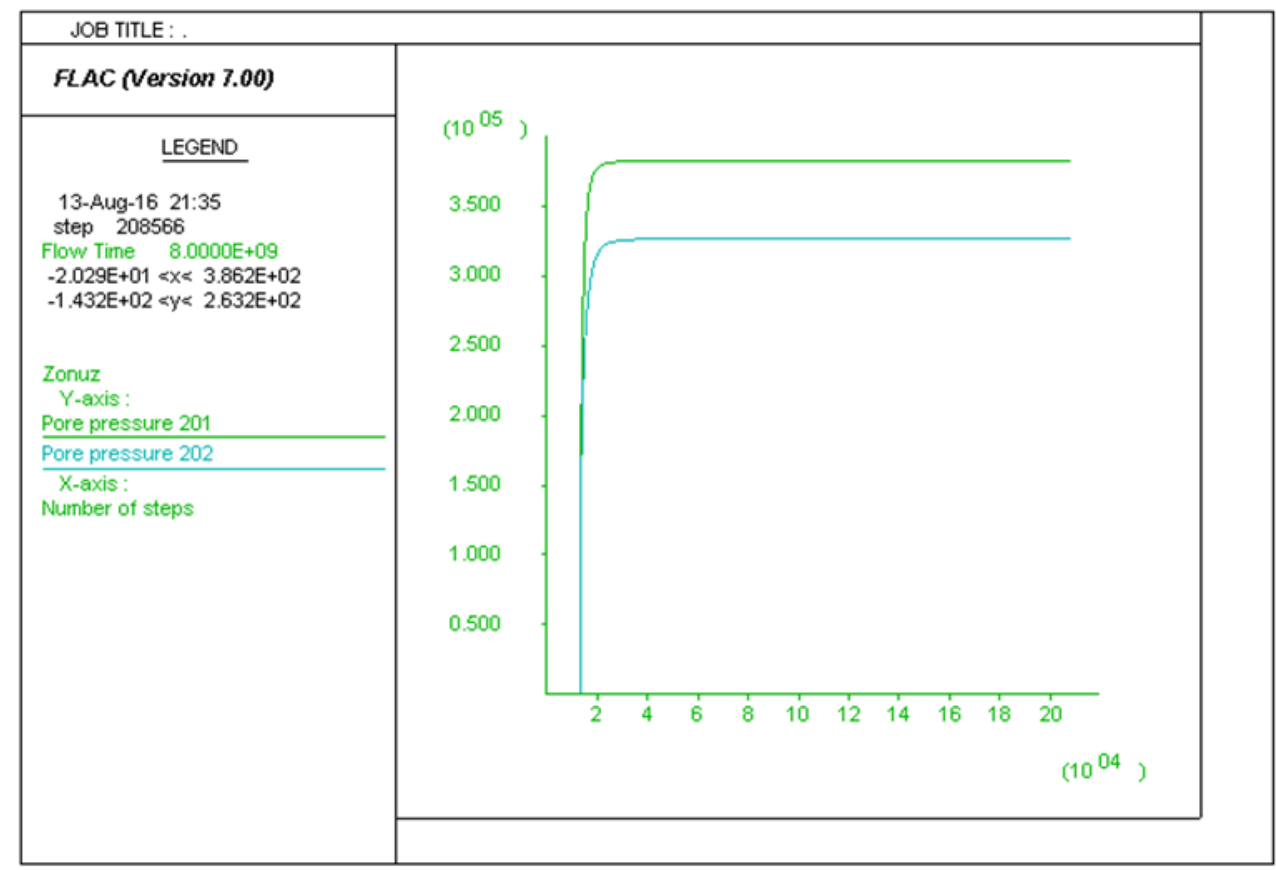

Graph14- Pore water pressure at 1815.75 level piezometers of the sections of two dams

Table9. Comparison of piezometers of the level 1815.75

Difference

$(\%)$
Piezometric level of the software

Piezometric level of the instrument

$1855 \mathrm{~m}$

$1815.75+38.3$
$=1854.05(\mathrm{~m})$
$1815.75+32.7$
$=1848.45(\mathrm{~m})$
Installation height

Piezometer umber

$1815.75 \mathrm{~m}$

201

202

Two piezometers 201 and 202 of the same level were used for section 2 of the foundation to compare foundation behavior in the model with real condition and the results indicated that real condition is accurately modeled; showing that the model is appropriate for dynamic analysis.

\section{Results}

According to the results obtained by pressure variation graphs, piezometric level and pore water pressure ratio, it was observed that:

1. Out of 19 piezometers installed at dam body, upstream piezometers usually follow piezometric pressure of lake level.

2. The highest piezometric pressure at dam body was $397.52 \mathrm{KPa}$ that was recorded by piezometer 205 . 
3. In each of three instrumenting section, pore water pressure of the piezometers drops by moving upward.

4. FLAC software that uses finite difference method has high capability in both static and dynamic analyses including building completion, strengthening, seepage and vibration. The results of analyses confirm good performance of this software in the field of vibrating geotechnic.

5. In watering phase, all piezometers in the foundation in both sections responded to increased level of the lake. The response was lower for piezometers of section 2 compared to those installed in section 1. The highest piezometric level was achieved in upstream piezometers of section 1 between 17 and $31 \mathrm{~m}$ and also in downstream piezometers between 40 and $48 \mathrm{~m}$ below lake elevation.

6. Pressure drop value by downward and upward movement in side section 1 $(0+82 \mathrm{Km})$ was higher than middle section $2(0+110 \mathrm{Km})$.

7. Pore pressure inside clay core increased by increase in lake water elevation and reached maximum value of $233.10 \mathrm{KPa}$ in piezometer $\mathrm{V} 150-\mathrm{U} 10-1852$ located in section

\section{References}

Abdel-Ghaffar, A.M., (1982), "Three Dimensional Dynamic Analysis of Nonhomogeneous Earth Dams", Soil. Dyn. \& Earthq. Engrg., Vol. 1,No. 3,pp 136-144.

Cook, R.D., Malakus, D. S. and Plesha, M. E., "Concepts and Applications of Finite Element Analysis “" John Wiley \& Sons, 1989.

Delvari Nejadian, A., Kaman Bedast, A., Hasounizadeh, H. 2011. Stability analysis of Maroun embankment dam using ANSYS and Get Studio software. Journal of water engineering; 3: 31-40

"Earthquake Analysis for Dams", State of the Art, ICOLD,International Commission on Large Dams, bulletin n52, Paris, 1986.

Finn, W.D.L., (1995), “ Modern Practice in Seismic Response Analysis of Embankment Dams”, Second International Conference on seismology and Earthquake Engineering, Keynote Lecture, May, Tehran, Islamic Republic of Iran.

Gazets, G., (1985), “Seismic Response of Earth Dams : Some Recent Developments “, Soil. Dyn. \& Earthq. Engrg., State-of-the-Art issue, Vol. 6, No. 1,pp 1-47.

ITASCA Consulting Group, (2001), "Fast Lagrangian Analysis of Continua-FLAC Code' s technical manuals".

ITASCA Consulting Group, (2001). "Fast Lagrangian Analysis of Continua-FLAC Code's technical manuals" Dynamic Manual..

Makdisi, F.I. \& Seed, H. B., (1987), “ Simplified Procedure for Estimating Dam and Embankment Earthquake induced Deformations”, ASCE, Journal of Geotechnical Engineering, Vol. 104, No. 7.

Pedro Simao Seco e Pinto, "Dynamic analysis of embankment dams", Soil Dynamics and Geotechnical Engineering, Seco e Pinto (ed.), 1993 Balkema, Rotterdam.

Pradel, D., Wartman, J and Binod, T, "Failure of the Fujinuma Dams during the 2011 Tohoku Earthquake" Geo-congress2013 ASCE 2013 .page 1566

Rahimi, H. 2006. Embankment dams, Tehran University Publication

Rahimi, H. 2010. Embankment dams, Tehran University Publication, $3^{\text {rd }}$ edition

Vermeer, P. A., And Borst, R. D., (1984), "Non- Associated Plasticity for Soils, Concrete and Rock", Heron, Vol. 29, No. 3, PP. 3-64.

Water and sewage organization, annual report from 2001 to 2012

Salehzadeh, H. 1995. Principles of soil mechanical engineering, Elm O Sanat publication, Tehran, $2^{\text {nd }}$ volume

Sadrnejad, S.A. 2005. Embankment dams and numerical analysis; Shahid Rajayi University publication, Iran

Serati, P., Mohamamdi, M., Manafpour, A. 2010. Evaluation of dynamic stability of embankment dams impressed by impermeable clay core. $5^{\text {th }}$ national congress of civil engineering. 
Zamiran, S. 2012. Modeling and analysis of rock fill and embankment dams in FLAC. Noavar publication, $1^{\text {st }}$ edition

Tahouni, S. 1997. Principles of geotechnic engineering, Pars Ayin publication

Monthly journal of Iranian seismology network, ministry of road and civil development, Iran, no 11

Vafaeian, M. embankment dams, Jahad Daneshgahi publication, Isfahan technology branch

Vafaeian, M. 1990. Effect of earthquake on embankment dams, Jahad Daneshgahi publication, Isfahan technology branch

Vafaeian, M. 1998. Embankment dams, Jahad Daneshgahi publication, Isfahan technology branch, $1^{\text {st }}$ edition, summer

Vafaeian, M. 2005. Operational information on embankment dams, Karan publication, $1^{\text {st }}$ edition, spring 